\title{
Zapewnienie interoperacyjności kolei
}

\begin{abstract}
$W$ artykule opisano sposób postępowania PKP Polskie Linie Kolejowe S.A. podczas prowadzenia budowy i modernizacji infrastruktury kolejowej i przekazywania jej do eksploatacji, wynikajacy z wymagań prawa Unii Europejskiej oraz prawodawstwa krajowego dotyczacego interoperacyjności europejskich systemów kolei konwencjonalnej i kolei dużych prędkości. Szczególnq uwagę zwrócono na rolę zarzqdcy infrastruktury, jej upoważnionego przedstawiciela, jednostek notyfikowanych i narodowego organu bezpieczeństwa, jakim jest Urzad Transportu Kolejowego, w niezbędnym procesie oceny zgodności składników interoperacyjnościi podsystemów kolejowych.

(Materiat do artykutu przedstawiono w formie prezentacji na Międzynarodowych Targach Poznańskich - Transporta 2009 - Transport Szynowy XXI wieku dla Polski.)
\end{abstract}

\author{
Znaczenie stosowanych skrótów: \\ PKP PLK S.A. - PKP Polskie Linie Kolejowe Spótka Akcyjna \\ UTK - Urzad Transportu Kolejowego \\ PCA - Polskie Centrum Akredytacji \\ ERA - Europejska Agencja Kolejowa (European Railway Agency) \\ CER - Stowarzyszenie Kolei Europejskich (Community of Railway and Infrastructure Companies) \\ TSI - techniczna specyfikacja interoperacyjności \\ INF - podsystem Infrastruktura \\ ENE - podsystem Energia \\ CCS - podsystem Sterowanie \\ RST-podsystem Tabor \\ WAG - podsystem Tabor Wagony Towarowe \\ OPE - podsystem Ruch Kolejowy \\ TAF - podsystem Aplikacje Telematyczne dla Ruchu Towarowego \\ TAP - podsystem Aplikacje Telematyczne dla Ruchu Pasażerskiego \\ $M A I$ - podsystem Utrzymanie \\ SRT-Bezpieczeństwo w Tunelach Kolejowych \\ PRM - Osoby z Ograniczona Zdolnościa Poruszania się \\ POIiŚ - program operacyjny Infrastruktura i Środowisko
}

\section{Wstęp}

Członkostwo Polski w Unii Europejskiej wymusza w obszarze transportu kolejowego przestrzeganie ustalonych wymagań dotyczących kolei, a w przypadku PKP PLK S.A. wymagań dotyczących podsystemu strukturalnego, jakim jest infrastruktura kolejowa. Zgodność $\mathrm{z}$ ustalonymi wymaganiami jest szczególnie istotna $\mathrm{w}$ przypadku modernizacji i budowy linii kolejowych, których koszt jest częściowo refundowany $\mathrm{z}$ funduszy europejskich, ponieważ refundacja taka jest możliwa tylko wtedy, gdy linie kolejowe spełniają wymagania dyrektyw dotyczących interoperacyjności kolei oraz związanych z nimi TSI.
PKP PLK S.A. jako zarządca infrastruktury kolejowej w Polsce zarządza aktualnie $20547 \mathrm{~km}$ linii kolejowych, przy czym $18993 \mathrm{~km}$ stanowią linie eksploatowane, a $1614 \mathrm{~km}$ linie $\mathrm{z}$ ruchem czasowo zawieszonym. Plany modernizacyjne zakładają $\mathrm{w}$ niedługim czasie modernizację około $4000 \mathrm{~km}$ linii. Warto zauważyć, że w 2008 r. PKP PLK S.A. zrealizowały inwestycje za ok.3 mld PLN, a w roku 2009 planowane nakłady na realizację inwestycji wynoszą ok. 3,9 mld PLN. Jest to więc znaczący wzrost (ok. 30\%). Wielkość i obszar realizowanych inwestycji przedstawia rys. 1. 


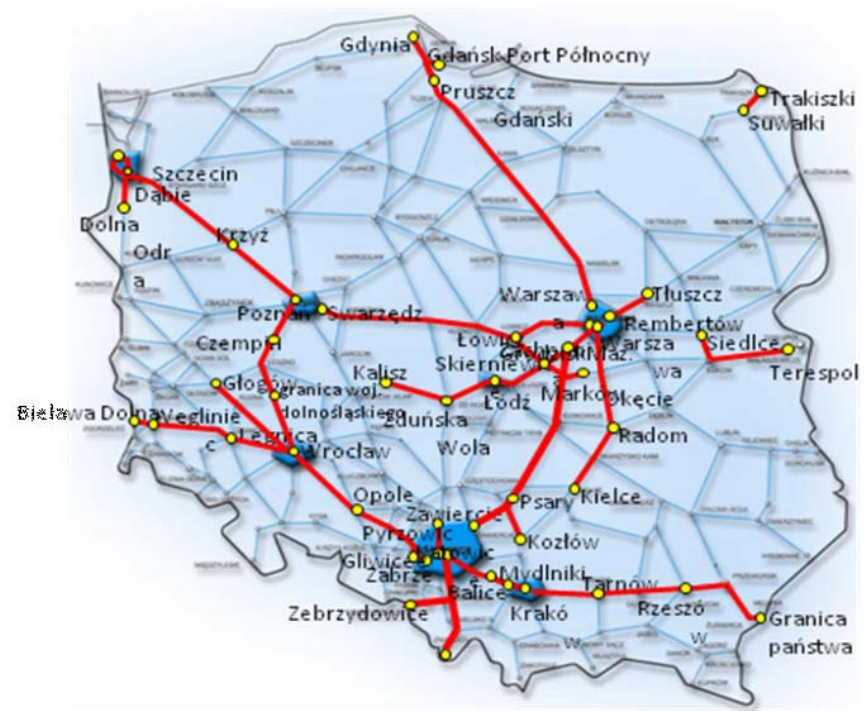

Rys. 1. Modernizowane linie kolejowe

Znacząca część inwestycji jest realizowana w ramach POIiŚ. W latach 2007 - 2013 PKP PLK S.A. planują realizację 25 projektów inwestycyjnych, które sa umieszczone na liście podstawowej i 7 projektów umieszczonych na liście rezerwowej POIiŚ. Koszt realizacji projektów z listy podstawowej wynosi ok. 24,4 mld PLN, z czego około 64\% zostanie dofinansowane $\mathrm{z}$ funduszy UE (szacunkowa kwota dofinansowania około 15,6 mld PLN). W przypadku realizacji projektów z listy rezerwowej ich koszt szacuje się na ok. 9,6 mld PLN przy dofinansowaniu około $68,8 \%$ (ok. 6,6 mld PLN).

Wszystkie linie wchodzące w skład korytarzy europejskich oraz linie modernizowane i nowo budowane, a szczególnie te, których koszt modernizacji i budowy jest współfinansowany przez UE, muszą spełniać wymagania obowiązujących dyrektyw dotyczących interoperacyjności kolei oraz dyrektyw dotyczących bezpieczeństwa. Poprzez interoperacyjność kolei rozumie się zdolność transeuropejskiego systemu kolei dużych prędkości i transeuropejskiego systemu kolei konwencjonalnej do bezpiecznego i niezakłóconego ruchu pociagów na terenie państw członkowskich Unii Europejskiej, polegająca na spełnieniu zasadniczych wymagan dotyczących interoperacyjności kolei. Zatem umieszczanie wyrobów na rynku kolejowym oraz oddawanie podsystemów lub ich części do eksploatacji musi się odbywać zgodnie z regulacjami prawnymi przyjętymi $\mathrm{w}$ UE i transponowanymi do prawodawstwa krajowego.

\section{Europejskie regulacje prawne dla kolei}

Od samego początku powstania Unii Europejskiej idea, która przyświecała wiodącym państwom członkowskim, było doprowadzenie do swobodnego przepływu osób, towarów i kapitału. Aby to osiagnąć, postawiono sobie ambitny cel doprowadzenia do integracji europejskiego systemu kolejowego, który mógłby zapewnić realizację usług transgranicznych bez konieczności dotychczas wymaganej zmiany przewoźnika i przy jednoczesnym zapewnieniu ich najwyższej jakości. W tym celu została powołana Europejska Agencja Kolejowa (ERA). Ma ona za zadanie opracowanie dokumentów ustalających zasady interoperacyjności. Dokumentami definiującymi podstawy funkcjonowania jednolitego systemu oceny zgodności z zasadami interoperacyjności są dyrektywy, TSI oraz przywołane przez nie normy europejskie i inne dokumenty normatywne w całości lub w wyspecyfikowanych częściach.

Strukturę dokumentów i powiązanie między nimi przedstawiono schematycznie na rys. 2 .

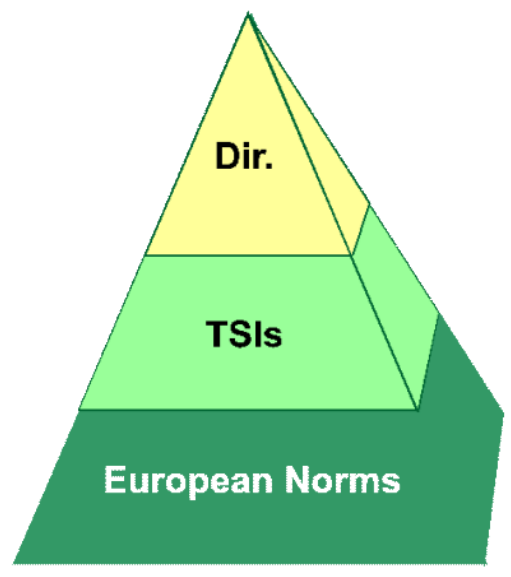

Dyrektywy

Specyfikacje Techniczne Interoperacyjności (TSI)

Normy (np. CEN, CENELEC, ETSI) Specyfikacje (np. GSM-R, ETCS)

Rys. 2. Struktura ważności dokumentów regulujących interoperacyjność

Dyrektywy unijne w obszarze kolejowym odnoszą się do:

- rozwoju kolei wspólnoty,

- licencjonowania przewoźników,

- alokacji przepustowości infrastruktury,

- certyfikacji bezpieczeństwa,

- interoperacyjności.

Ustawodawca unijny sankcjonując 2 systemy kolei europejskich, tj. system kolei dużych prędkości i system kolei konwencjonalnej, uregulował interoperacyjność następującymi dyrektywami:

- Dyrektywą 48/96/WE w sprawie interoperacyjności transeuropejskiego systemu kolei dużych prędkości (Dz. Urz. UE nr L 235 z dnia 17.09.1996 r.),

- Dyrektywą 2001/16/WE w sprawie interoperacyjności transeuropejskiego systemu kolei konwencjonalnej (Dz. Urz. UE nr L $110 \mathrm{z}$ dnia 20.04.2001 r.),

- Dyrektywą 2004/50/WE zmieniającą dyrektywy 48/96/WE i 2001/16/WE i zapowiadającą stopniowe rozszerzanie zakresu ich stosowania (Dz. Urz. UE nr L 164 z dnia 30.04.2004 r.), 
- Dyrektywą 2007/32/WE zmieniającą dyrektywy 48/96/WE i 2001/16/WE i wprowadzającą kontrolę wstępną oraz pośrednie certyfikaty i deklaracje zgodności (Dz. Urz. UE nr L $141 \mathrm{z}$ dnia 02.06.2007 r.),

- Dyrektywą 2008/57/WE w sprawie interoperacyjności systemu kolei we Wspólnocie konsolidująca dyrektywy 48/96/WE i 2001/16/WE i przesądzającą rozszerzenie zakresu stosowania od 2012 r. na cały system kolejowy $\mathrm{i}$ ewentualnie szynowe systemy miejskie (Dz. Urz. UE nr L 191 z dnia 18.07.2008 r.)

Podstawowymi dokumentami zawierającymi szczegółowe wymagania dla spełnienia interoperacyjności są TSI. Mogą one przywoływać w całości lub w częściach normy europejskie $i$ inne dokumenty normalizacyjne, jak np. Karty UIC. W przypadku przywołania normy lub dokumentu normatywnego obowiązują one w całości. W przypadku przywołania konkretnych punktów tych dokumentów obowiązujące stają się tylko przywołane punkty.

TSI opracowywane są przez ERA przy współpracy ekspertów z organizacji stale z nią współpracujących. Oprócz reprezentantów regulatorów rynku kolejowego państw członkowskich (w Polsce takim regulatorem jest Prezes UTK) stale współpracują z ERA następujące organizacje:

- ALE Autonome Lokomotivfuhrer - Gewerkschaften Europa,

- CER Community of European Railway and Infrastructure Companies,

- EIM European Rail Infrastructure Managers,

- ERFA European Rail Freight Association,

- ETF European Transport Workers Federation,

- UNIFE Association of European Railway Industries,

- UIP International Union of Private Wagons,

- UITP International Association of Public Transport,

- UIRR International Union of Combined RoadRail Transport Companies,

- NB Rail (stowarzyszenie jednostek notyfikowanych do dyrektyw interoperacyjności kolei).

Jak z powyższego wynika $\mathrm{w}$ grupach roboczych ERA stale pracują reprezentanci przewoźników i zarządców infrastruktury, reprezentanci regulatorów rynku kolejowego państw członkowskich i reprezentanci NB Rail.

PKP PLK S.A. poprzez członkostwo w CER mogą również wpływać na opracowywane przez ERA dokumenty.

Wdrażaniem w państwach członkowskich opracowanych przez ERA i zatwierdzonych przez Komisję Europejską dokumentów interoperacyjności zajmują się organa regulujące rynek kolejowy $\mathrm{w}$ danym kraju.
Europejskie wymagania dla kolei konwencjonalnej określają aktualnie następujące TSI:

- CR TSI TAF - Aplikacje telematyczne dla ruchu towarowego (Dz. Urz. UE nr L $13 \mathrm{z}$ dnia 18.01.2006 r.),

- CR TSI NOI - Hałas (Dz. Urz. UE nr L 37 z dnia 08.02.2006 r.),

- CR HS TSI CCS - Sterowanie (Dz. Urz. UE L 284 z dnia 16.10.2006 r.) i Aneks A (Dz. Urz. UE L 136 z dnia 24.05.2008 r.),

- CR TSI WAG - Tabor. Wagony towarowe (Dz. Urz. UE nr L 344 z dnia 08.12.2006 r.),

- CR TSI OPE - Ruch kolejowy (Dz. Urz. UE nr L 359 z dnia 18.12.2006 r.),

- CR HS TSI PRM - Osoby z ograniczona zdolnością poruszania się (Dz. Urz. UE nr L 64

z dnia 07.03.2008 r.),

- CR HS TSI SRT - Bezpieczeństwo w tunelach kolejowych (Dz. Urz. UE nr L 64 z dnia 07.03.2008 r.).

Aktualnie opracowywane są przez ERA lub poddawane konsultacjom następujące specyfikacje CR TSI tzw. trzeciego priorytetu, to jest:

- CR TSI INF - Infrastruktura; w lutym/marcu 2008 r. określano szczególne przypadki dla Polski, ostateczny projekt dokumentu powstał w październiku 2008 r.,

- CR TSI ENE - Energia; w lutym/marcu 2008 określano szczególne przypadki dla Polski, ostateczny projekt dokumentu powstał w październiku 2008 r.,

- CR TSI RST - Tabor trakcyjny i wagony pasażerskie; w lutym/marcu 2008 określano szczególne przypadki dla Polski, ostateczny projekt dokumentu powstał w kwietniu 2009 r.,

- CR TSI TAP - Aplikacje telepatyczne dla przewozów pasażerskich; przewidywana data ostatecznej wersji projektu dokumentu: wrzesień 2009 r.

Europejskie wymagania dla kolei dużych prędkości określają następujące TSI:

- HS TSI Sterowanie (Dz. Urz. UE nr L 284 z dnia 16.10.2006 r.) oraz Aneks A (Dz. Urz. UE nr L 342 z dnia 07.12.2006 r.),

- HS TSI Infrastruktura (Dz. Urz. UE nr L 77 z dnia 19.03.2008 r.),

- HS TSI Energia (Dz. Urz. UE nr L 104 z dnia 14.04.2008 r.),

- HS TSI Ruch kolejowy (Dz. Urz. UE nr L 84 $\mathrm{z}$ dnia 26.03.2008 r.),

- HS TSI Tabor (Dz. Urz. UE nr L 84 z dnia 26.03.2008 r.).

Obowiązujące wspólne dla kolei dużych prędkości i kolei konwencjonalnej specyfikacje techniczne interoperacyjności to TSI CCS, TSI PRM, TSI SRT i TSI Hałas. 
Polski ustawodawca przeniósł do polskiego prawa dyrektywę dotyczącą transeuropejskiego systemu kolei dużych prędkości (48/96/WE) i dyrektywę dotyczącą transeuropejskiego systemu kolei konwencjonalnej (2001/16/WE) ustawą $z$ dnia 28.03.2003 r. o transporcie kolejowym (Dz. U. 2003 nr 86, poz. 789 z późniejszymi zmianami; tekst jednolity Dz. U. 2007 nr 16, poz. 94).

Odniesienie się do TSI nastąpiło rozporządzeniami Ministra Infrastruktury:

- $\quad$ z dnia 07.01. 2008 r. w sprawie zasadniczych wymagań dotyczących interoperacyjności kolei oraz procedur oceny zgodności dla transeuropejskiego systemu kolei dużych prędkości (Dz. U. $2008 \mathrm{nr} 11$, poz. 64),

- $\quad$ z dnia 07.01.2008 r. w sprawie zasadniczych wymagań dotyczących interoperacyjności kolei oraz procedur oceny zgodności dla transeuropejskiego systemu kolei konwencjonalnej (Dz. U. 2008 nr 11, poz. 65).

Wszystkie wymienione akty prawne odnoszą się ogólnie również do procesów oceny zgodności wyrobów i podsystemów, które muszą być przeprowadzane przed ich umieszczeniem na rynku lub oddaniem do eksploatacji. Podstawową ustawą odnoszącą się do oceny zgodności jest Ustawa z dnia 30.08.2002 r. o systemie oceny zgodności (Dz. U. 2002 nr 166, poz. 1360 z późniejszymi zmianami). W ustawie tej wyznaczono PCA jako jednostkę udzielającą akredytacji laboratoriom badawczym i jednostkom certyfikujacym. Ustalono w niej również, że Prezes UTK na podstawie wcześniejszej akredytacji PCA udziela autoryzacji takim jednostkom w obszarze kolejowym. Po uzyskaniu autoryzacji Prezesa UTK jednostki te moga być notyfikowane w Komisji Europejskiej jako kompetentne do przeprowadzania procesów oceny zgodności.

\section{Certyfikacja krajowa i europejska}

Ze względu na to, że nie wszystkie podsystemy kolei konwencjonalnej są uregulowane prawodawstwem unijnym (brak jeszcze TSI INF, TSI ENE, TSI RST i TSI TAP), państwa członkowskie stosują w tych obszarach prawodawstwo krajowe. W Polsce Prezes UTK wydaje świadectwa dopuszczenia typu lub świadectwa autoryzacji na systemy i urządzenia, które są zgodne $\mathrm{z}$ wymaganiami krajowymi. Regulowane to jest następującymi aktami prawnymi:

- Rozporządzenie Ministra Infrastruktury z dnia 26.09.2003 r. w sprawie wykazu typów budowli i urządzeń przeznaczonych do prowadzenia ruchu kolejowego oraz typów pojazdów kolejowych, na które wydawane są świadectwa dopuszczenia do eksploatacji (Dz. Urz. 2003 nr 175, poz. 1706),
- Rozporządzenie Ministra Infrastruktury z dnia 30.04.2004 r. w sprawie świadectw dopuszczenia do eksploatacji typu budowli i urządzeń przeznaczonych do prowadzenia ruchu kolejowego oraz typu pojazdu kolejowego (Dz. Urz. 2004 nr 103, poz. 1090),

- Obwieszczenie Prezesa Urzędu Transportu Kolejowego z dnia 08.08.2005 r. w sprawie ustalenia listy właściwych krajowych specyfikacji technicznych i dokumentów normalizacyjnych, których zastosowanie umożliwi spełnienie zasadniczych wymagań dotyczących interoperacyjności kolei (Dz. Urz. Ministra Infrastruktury $2005 \mathrm{nr} 9$, poz. 62).

W przypadku, gdy dla wyrobów (składników interoperacyjności i podsystemów) istnieją stosowne TSI, stosuje się ocenę zgodności na zgodność z tymi wymaganiami.

\section{Umieszczanie składników interoperacyjności na rynku}

Aby wyrób, którym jest składnik interoperacyjności mógł zostać umieszczony na rynku, jego producent lub upoważniony przedstawiciel musi wystawić dokument, który nazywa się deklaracją zgodności. Wystawienie takiej deklaracji zgodności kończy proces certyfikacji. Zaczyna się on wyborem przez producenta lub jego upoważnionego przedstawiciela jednostki notyfikowanej, która dokona oceny zgodności wyrobu (tylko w przypadku, gdy wymagają tego moduły oceny opisane w stosownej TSI). Po stwierdzeniu, że wyrób spełnia wszystkie wymagania narzucone właściwą TSI jednostka notyfikowana dokonująca oceny wystawia certyfikat zgodności, na którego podstawie może zostać wystawiona deklaracja zgodności i wyrób umieszczony na rynku. Schematycznie proces oceny zgodności składnika interoperacyjności przedstawia rys. 3 .

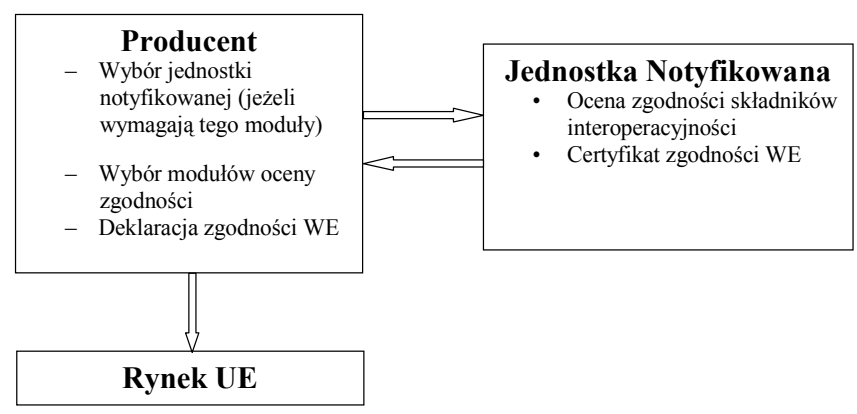

Rys. 3. Proces oceny zgodności składnika interoperacyjności

\section{Oddawanie podsystemów do eksploatacji}

Aby wyrób, którym jest podsystem, mógł zostać oddany do eksploatacji, jego producent lub upoważniony przedstawiciel lub jednostka kontraktująca musi 
otrzymać od regulatora rynku kolejowego w danym państwie członkowskim (w Polsce od Prezesa UTK) świadectwo dopuszczenia typu lub świadectwo autoryzacji. Świadectwa te wystawiane sa po spełnieniu wszystkich wymagań interoperacyjności kolei, jak również wymagań bezpieczeństwa. Dowodem na ich spełnienie jest deklaracja weryfikacji zgodności podsystemu wystawiona przez producenta lub jego upoważnionego przedstawiciela albo jednostkę kontraktująca oraz zebrana $\mathrm{w}$ czasie procesu oceny zgodności dokumentacja. Podobnie jak w przypadku składników interoperacyjności wystawienie takiej deklaracji weryfikacji zgodności kończy proces certyfikacji. Zaczyna się on wyborem przez producenta lub jego upoważnionego przedstawiciela lub przez jednostkę kontraktująca jednostki notyfikowanej, która dokona oceny zgodności. Po stwierdzeniu, że wyrób spełnia wszystkie wymagania narzucone właściwą TSI, jednostka notyfikowana dokonująca oceny wystawia certyfikat weryfikacji zgodności podsystemu, na którego podstawie może zostać wystawiona deklaracja weryfikacji zgodności podsystemu i może on aplikować o świadectwo dopuszczenia typu lub świadectwo autoryzacji. Proces oceny zgodności interoperacyjnego podsystemu przedstawia schematycznie rys. 4 .

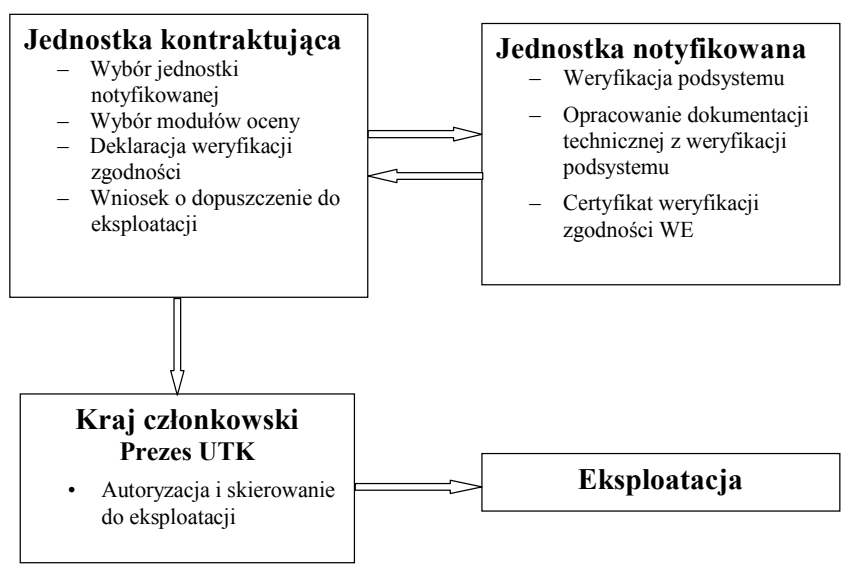

Rys. 4. Proces oceny zgodności interoperacyjnego podsystemu

Ponieważ wyprodukowanie i oddanie do eksploatacji niektórych podsystemów (dotyczy to w szczególności infrastruktury i taboru) jest długotrwałe i kosztowne, więc aby uniknać niepotrzebnych kosztów produkcji w przypadku niespełnienia wymagań TSI dla podsystemu finalnego dyrektywą 2007/32/WE z dnia 01.06.2007 r. dopuszczono dokonywanie oceny zgodności na etapach:

- projektu ogólnego (włącznie z badaniami ty$\mathrm{pu}$,

- budowy konstrukcji, w tym np. prac w zakresie inżynierii lądowej i wodnej, wytwarzania, montażu jego składników oraz całościowego dostosowania,

- końcowych prób podsystemu.
W takim przypadku po pomyślnej ocenie zgodności etapu jednostka notyfikowana wystawia pośredni certyfikat weryfikacji podsystemu, a wykonawca lub jego upoważniony przedstawiciel na tej podstawie deklarację WE pośredniej zgodności podsystemu dla danego etapu. Takie rozwiązanie będzie często stosowane $\mathrm{w}$ PKP PLK S.A.

\section{Możliwości stosowania odstępstw od wymagań dyrektyw}

Jak już wspomniano wcześniej, ostatnio ustanowioną dyrektywą interoperacyjności kolei jest opublikowana w Dzienniku Urzędowym UE nr L 191 z dnia 18.07.2008 r. dyrektywa nr 2008/57/WE w sprawie interoperacyjności systemu kolei we Wspólnocie, która konsoliduje dyrektywy 48/96/WE i 2001/16/WE. Od roku 2012 będzie ona obowiązywać cały system kolejowy i ewentualnie szynowe systemy miejskie. Dyrektywa ta dopuszcza możliwość odstąpienia od jej stosowania dla:

- projektów będących w zaawansowanym stadium realizacji,

- projektów odnowy lub modernizacji istniejącego już podsystemu, jeśli skrajnia ładunku, prześwit toru, szerokość międzytorza lub napięcie sieci elektrycznej w TSI są niezgodne $\mathrm{z}$ istniejącymi w podsystemie,

- planowanego nowego podsystemu albo planowanego odnowienia lub modernizacji istniejącego już podsystemu na terytorium tego państwa członkowskiego, którego sieć kolejowa jest oddzielona lub odizolowana,

- planowanego odnowienia, rozszerzenia lub modernizacji istniejącego już podsystemu, jeśli stosowanie TSI wpłynęłoby na opłacalność ekonomiczną projektu lub byłoby niezgodne $\mathrm{z}$ systemem kolejowym państwa członkowskiego,

- w przypadku, gdy w następstwie wypadku lub klęski żywiołowej warunki szybkiej odbudowy sieci nie pozwalają ze względów ekonomicznych lub technicznych na częściowe lub całkowite stosowanie odpowiednich TSI,

- w przypadku pojazdów jadących z państw trzecich lub do państw trzecich, w których prześwit toru różni się od prześwitu toru głównej sieci Wspólnoty.

Działalność PKP PLK S.A. na rzecz interoperacyjności kolei

PKP PLK S.A. prowadzą szeroką działalność na rzecz interoperacyjności kolei.

Został powołany zespół ds. interoperacyjności, doskonalony jest system zarządzania bezpieczeństwem. Opracowywane są wymagania dla oceny zgodności produktów z TSI dla potrzeb infrastruktury kolei konwencjonalnych i kolei dużych prędkości oraz standardy techniczne dla linii nowo budowanych i 
modernizowanych. Infrastruktura jest dostosowywana dla obsługi osób z ograniczoną zdolnością poruszania się, poprawia się stan bezpieczeństwa skrzyżowań linii kolejowych $\mathrm{z}$ drogami kołowymi. Prowadzone jest pilotażowe wdrożenie systemu zasilania trakcji $25 \mathrm{kV}$ prądu przemiennego.

Przedstawiciele PKP PLK S.A. biorą udział w pracach normalizacyjnych na szczeblu krajowym i europejskim.

\section{Wnioski}

Stosowanie tylko certyfikowanych składników interoperacyjności i podsystemów pozwala na:

- usprawnienie funkcjonowania PKP PLK S.A. W zakresie procesu decyzyjnego oraz podczas planowania i realizacji inwestycji,

- wykonanie budowy/modernizacji linii kolejowych zgodnie $\mathrm{z}$ wymogami TSI i tym samym uzyskanie dofinansowania z Unii Europejskiej.

Należy jednak zdawać sobie sprawę z tego, że pełne spełnienie wymagań interoperacyjności kolei wymagać będzie znaczących nakładów finansowych oraz szeregu szkoleń mających na celu podniesienie poziomu wiedzy personelu PKP PLK S.A. na ten temat.

\section{Literatura}

1. Dyrektywa 48/96/WE w sprawie interoperacyjności transeuropejskiego systemu kolei duzych prędkości (Dz. Urz. UE nr L 235 z dnia 17.09.1996 r.),

2. Dyrektywa $2001 / 16 / W E$ w sprawie interoperacyjności transeuropejskiego systemu kolei konwencjonalnej (Dz. Urz. UE $n r \quad L \quad 110$ z dnia 20.04.2001 r.),
3. Dyrektywa 2004/50/WE zmieniajaca dyrektywy 48/96/WE i 2001/16/WE i zapowiadajaca stopniowe rozszerzanie zakresu ich stosowania (Dz. Urz. UE nr L 164 z dnia 30.04.2004 r.),

4. Dyrektywa 2007/32/WE zmieniajaca dyrektywy 48/96/WE $i$ 2001/16/WE $i$ wprowadzajaca kontrolę wstępna oraz pośrednie certyfikaty i deklaracje zgodności (Dz. Urz. UE $n r \quad L \quad 141$ z dnia 02.06 .2007 r.),

5. Dyrektywa 2008/57/WE w sprawie interoperacyjności systemu kolei we Wspólnocie konsolidujaca dyrektywy 48/96/WE i 2001/16/WE i przesqdzajaca rozszerzenie zakresu stosowania od 2012 r. na caly system kolejowy $i$ ewentualnie szynowe systemy miejskie (Dz. Urz. UE $n r$ L 191 z dnia 18.07.2008 r.),

6. Ustawa z dnia 30.08.2002 r. o systemie oceny zgodności (Dz. U. 2002 nr 166, poz. 1360 z późniejszymi zmianami),

7. Ustawa z dnia 28.03.2003 r. o transporcie kolejowym (Dz. U. 2003 nr 86, poz. 789 z późniejszymi zmianami; tekst jednolity Dz. U. 2007 nr 16, poz. 94),

8. Rozporzqdzenie Ministra Infrastruktury $z$ dnia 07.01. 2008 r. w sprawie zasadniczych wymagań dotyczacych interoperacyjności kolei oraz procedur oceny zgodności dla transeuropejskiego systemu kolei dużych prędkości (Dz. U. 2008 nr 11, poz. 64),

9. Rozporzqdzenie Ministra Infrastruktury $z$ dnia 07.01.2008 r.w sprawie zasadniczych wymagań dotyczacych interoperacyjności kolei oraz procedur oceny zgodności dla transeuropejskiego systemu kolei konwencjonalnej (Dz. U. $2008 \mathrm{nr}$ 11, poz. 65),

10. Obwieszczenie Prezesa Urzędu Transportu Kolejowego z dnia 08.08.2005 r. w sprawie ustalenia listy właściwych krajowych specyfikacji technicznych i dokumentów normalizacyjnych, których zastosowanie umożliwi spetnienie zasadniczych wymagań dotyczacych interoperacyjności kolei (Dz. Urz. Ministra Infrastruktury $2005 \mathrm{nr}$ 9, poz. 62). 